\title{
Analisis Kinerja Pelayanan Operasional Terminal Petikemas Pelabuhan Soekarno Hatta
}

\author{
Ruslin \\ Tenaga Pengajar, Program Studi Manajemen Pelabuhan, \\ Akademi Ilmu Pelayaran Nusa Tenggara, Nusa Tenggara Barat, Indonesia \\ Email: ruslin@aipnusra.ac.id
}

\begin{abstract}
Abstrak. Terminal petikemas pelabuhan Soekarno Hatta Makassar merupakan terminal terbesar dibawah naungan PT.Pelindo IV, yang melayani kegiatan bongkar muat barang domestik dan internasional. Dukungan lokasi yang cukup strategis serta pelayanan pelabuhan hingga 24 jam, menjadikan pelabuhan tersebut sibuk dengan berbagai aktivitas sehingga perlu melakukan analisis kinerja pelayanan terminal petikemas. Penelitian ini menggunakan metode kuantitatif karena analisis data dilakukan dengan menghitung nilai Berth Occupancy Ratio, Yard Occupancy Ratio dan kapasitas terpasang untuk alat angkat $G C$ dan $R T G$, serta metode regresi linear sederhana dimana persamaan tersebut mampu menginterpretasikan kondisi yang terjadi dilapangan. Hasil penelitian menunjukkan bahwa kinerja dermaga terminal petikemas untuk kondisi eksisting dinyatakan baik karena berada dibawah standar yang di sarankan oleh UNCTAD dengan capaian nilai BOR sebesar 56.4\%, hal yang sama juga terjadi pada lapangan penumpukan dimana nilai YOR 34.7\% atau setara dengan luas 43.853 $\mathrm{m}^{2}$. Sedangkan kinerja alat angkat dinyatakan baik karena pemanfaatan alat angkat jenis CC 57.14\% dan alat angkat jenis RTG 77.77\%. Kinerja dermaga mengalami penurunan pada tahun 2027 berdasarkan hasil analisis diketahui nilai BOR 2027 mencapai 98.4\%, untuk mengantisipasi terjadinya penumpukan kapal di area pelabuhan maka perlu melakukan penambahan panjang dermaga menjadi $1.972 \mathrm{~m}$, tingkat pemanfaatan lapangan penumpukan pada tahun 2027 dinyatakan masih baik dengan capaian nilai YOR sebesar 43.9\%, pemanfaatan alat angkat pada tahun 2027 untuk jenis CC sebanyak 5 unit dari 7 unit yang tersedia, alat angkat jenis RTG 18 unit dari 18 unit yang tersdia.
\end{abstract}

Kata Kunci : Kunjungan Kapal, Arus Barang, Bongkar Muat 
Jurnal Ilmu Sosial dan Pendidikan

http://ejournal.mandalanursa.org/index.php/JISIP/index

Terakreditasi Peringkat 5 (No. SK: 85/M/KPT/2020)

\section{PENDAHULUAN}

\section{Latar Belakang}

Terminal petikemas pelabuhan Soekarno

Hatta merupakan terminal terbesar dibawah naungan PT.Pelindo IV. Lokasi yang cukup strategis di Kota Makassar sebagaimana ditunjukkan pada Gambar 1. Terminal tersebut merupakan salah satu terminal yang melayani kegiatan bongkar muat barang domestik dan internasional, dengan dukungan alur pelayaran sepanjang 2 mil, PT Pelindo yakin atas implementasi misi perusahaan yaitu menjadi penggerak dan pendorong pertumbuhan ekonomi Indonesia Tengah dan Timur, Gambar 1 Sebaran Lokasi Pelabuhan Cabang PT.Pelindo IV

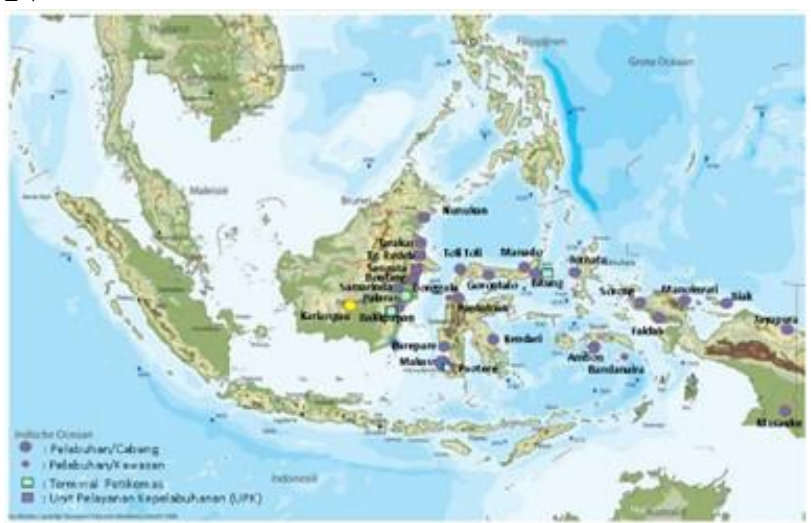

(Sumber: PT.Pelindo IV Cabang Makassar, 2012)

$\begin{array}{rrrr}\text { Sadar akan pentingnya terminal } & \text { petikemas dalam mendukung } & \text { kegiata }\end{array}$ perdagangan maka manajemen pelabuhan terus meningkatkan pelayanan jasa dipelabuhan tersebut, dengan membuka layanan 24 jam, menjadi bukti akan keseriusan pihak manajemen beserta pemerintah daerah dalam mendorong partumbuhan perekonomian Kawasan Timur Indonesia, akan tetapi dengan menerapkan pelayanan 24 jam, belum cukup untuk dijadikan acuan akan kemampuan terminal petikemas dalam melayani arus barang. Tingginya permintaan pasar akan komoditas tertentu menjadikan terminal petikemas sibuk dengan kegiatan bongkar muat, sehingga perlu dilakukan analisis kinerja pelayanan demi mendukung kegiatan bongkar muat. Beberapa
Vol. 5. No. 2 Maret 2021

p-ISSN: 2598-9944 e-ISSN: 2656-6753 komoditas unggulan yang berhasil diekspor melalui terminal petikemas Makassar diantaranya hasil perikanan dan rumput laut, komoditas tersebut tidak hanya berasal dari daerah hinterland, beberapa komoditas di supplay dari pelabuhan-pelabuhan yang berada di Kawasan Timur Indonesia (KTI), seperti pelabuhan Pantoloan, pelabuhan Bitung, serta pelabuhan Sorong, daerah hinterland Pelabuhan Soekarno Hatta sendiri terdiri atas daerahdaerah yang berada di Provinsi Sulawesi Selatan, pengiriman barang dengan menggunakan petikemas terbilang aman dari berbagai kerusakan dan kehilangan, sehingga tidak sedikit industri yang melakukan pengiriman barang menggunakan petikemas, bukan hanya pengiriman barang antar pulau dalam satu negara akan tetapi lebih luas dengan mengirim barang keluar negeri antar pulau dan antar negara, luasnya jangkauan pasar tentu akan mempengaruhi kinerja pelabuhan itu sendiri, baik dari segi penangan petikemas yang akan di bongkar maupun yang akan di muat, pengaruh tersebut juga akan sangat berdampak pada optimalisasi penggunaan lapangan penumpukan serta kapasitas dermaga yang tersedia.

\section{Rumusan Masalah}

Terminal petikemas Makassar merupakan terminal yang memiliki potensi besar untuk dikembangkan selain karena lokasinya yang cukup strategis, TPM juga memiliki berbagai jenis komoditas unggulan di daerah hinterland yang berpeluang untuk di ekspor ke berbagai Negara, akan tetapi terdapat beberapa permasalahan yang sering kita temui dalam pengembangan pelabuhan itu sediri diantaranya.

a. Seberapa besar kemampuan dermaga terminal petikemas dalam melayani arus kapal.

b. Apakah terminal petikemas mampu melayani arus barang yang terus meningkat tiap tahunnya.

c. Apakah alat angkat yang tersedia di terminal petikemas mampu mendukung kegiatan bongkar muat barang di TPM. 
d. Seberapa besar kapasitas alat angkat di terminal petikemas untuk 10 tahun kedepan.

\section{Tujuan Penelitian}

Adapun tujuan penelitian berdasarkan permasalahan-permasalahan yang telah diuraikan diatas yaitu untuk:

a. mengetahui kinerja dermaga dan lapangan penumpukan terminal petikemas dalam melayani arus kapal dan barang tahun 2017,

b. memprediksi tingkat penggunaan dermaga dan lapangan penumpukan terminal petikemas untuk 10 tahun kedepan,

c. mengukur kinerja peralatan bongkar muat di terminal petikemas tahun 2017,

d. memprediksi kapasitas alat angkat dalam melayani arus barang untuk 10 tahun kedepan.

\section{Batasan Masalah}

Dikarenakan luasnya cakupan permaslahan dalam penelitian ini dan terbatasnya waktu bagi penulis maka diperlukan batasan-batasan cakupan penelitian yaitu:

a. karena keterbatasan data yang diperoleh melalui TPM, terdapat 9 indikator kinerja pelayanan operasional menurut Keputusan Direktur Jenderal Perhubungan Laut, namun pada penelitian ini hanya menggunakan 3 indikator kinerja yaitu tingkat penggunaan dermaga, tingkat penggunaan lapangan penumpukan dan kapasitas operasi petalatan,

b. jenis peralatan yang di analisis yaitu $\mathrm{CC}$ dan RTG.

\section{Manfaat Penelitian}

Adapun manfaat yang diharapkan dari hasil penelitian ini yaitu:

a. sebagai bahan pertimbangan bagi pihakpihak pengelola pelabuhan dalam perencanaan pembangunan dan peningkatan kinerja saat ini dan di masa yang akan datang,

b. dapat digunakan sebagi acuan untuk penelitian-penelitian selanjutnya,

c. tambahan pengetahuan bagi penulis dalam memahami ilmu yang ditekuninya.

\section{Keaslian Penelitian}

Perbedaan dari penelitian-penelitian sebelumnya adalah pada penelitian ini penulis mengkhususkan perhitungan pemanfaatan dermaga terminal petikemas dengan menggunakan persamaan Berth Occupancy Ratio (BOR), dan perhitungan tingkat pemanfaatan lapangan penumpukan petikemas dengan menggunakan persamaan Yard Occupancy Ratio (YOR). Sedangakan pada penelitian yang dilakukan oleh Wahyu Prasetya hanya memprediksi kinerja untuk 5 tahun kedepan yaitu hingga tahun 2012, sedangkan untuk penelitian yang dilakukan oleh Iwid Wahyu Puteranto lebih focus pada analisis kelayakan desain rencana pengembangan prasarana pelabuhan.

\section{TINJAUAN PUSTAKA \\ Kinerja Pelayanan Operasional}

Kinerja pelayanan operasional adalah hasil kerja terukur yang dicapai pelabuhan dalam melaksanakan pelayanan kapal, barang, dan utilitas fasilitas dan alat dalam periode waktu dan satuan tertentu (Dirjen Perhubungan Laut, 2011). Indikator kinerja pelayanan pelabuhan yang pada umumnya digunakan dewasa ini dapat dikelompokkan sedikitnya atas tiga kelompok indikator, yaitu indicator output, indicator service, dan indicator utility (Uguy, et al., 2015). Analisa Kinerja Arus Kapal berdasarkan Indikator Service, indikator yang erat kaitannya dengan informasi mengenai lamanya waktu pelayanan kapal selama di dalam daerah lingkungan kerja pelabuhan (Uguy, et al., 2015). a. Waktu pelayanan di perairan adalah sejak kapal berada di lego jangkar sampai ikat tali di tambatan dan sebaliknya.

1) Waiting Time atau waktu tunggu. Pelayanan PT. Pelindo IV cabang Manado dimulai sejak kapal di perairan pelabuhan. Waiting time disini adalah waktu kapal menunggu pelayanan tambatan, pelayanan pandu atau tunda. 
2) Postpone Time atau waktu tertunda yang tidak bermanfaat selama kapal berada di perairan pelabuhan antara lokasi lego jangkar sebelum/ sesudah melakukan kegiatan yang dinyatakan dalam satuan jam.

3) Approach Time atau waktu atau jumlah jam yang dipergunakan selama pelayanan pemanduan, sejak kapal bergerak dari lego jangkar sampai ikat tali di tambatan dan sebaliknya.

b. Waktu pelayanan di tambatan adalah dihitung sejak ikat tali di tambatan sampai lepas tali, atau jumlah jam selama kapal berada di tambatan.

1) Turn Round Time (TRT) atau waktu pelayanan kapal di pelabuhan adalah jumlah jam selama kapal berada di pelabuhan yang dihitung sejak kapal tiba di lokasi lego jangkar sampai kapal berangkat meninggalkan lokasi lego jangkar, dinyatakan dalam satuan jam.

2) Berthing Time (BT) atau waktu tambat adalah jumlah jam selama kapal berada di tambatan, sejak kapal ikat tali sampai lepas tali di tambatan.

3) Effective Time (ET)/ Operation Time (OT) atau waktu efektif adalah jumlah riil yang dipergunakan untuk melakukan kegiatan bongkar muat dinyatakan dalam jam.

4) Not Operation Time (NOT) atau waktu tidak kerja adalah jumlah jam yang direncanakan kapal tidak bekerja selama berada di tambatan, termasuk waktu istirahat dan waktu menunggu buruh, serta waktu menunggu akan lepas tambat kapal dinyatakan dalam satuan jam.

5) Idle Time (IT) atau waktu terbuang adalah jumlah jam kerja yang tidak terpakai selama waktu kerja bongkar muat di tambatan.

\section{Analisis Kinerja Arus Kapal}

Analisa Kinerja Arus Kapal berdasarkan

Indikator Service, indikator yang erat kaitannya dengan informasi mengenai lamanya waktu pelayanan kapal selama di dalam daerah lingkungan kerja pelabuhan (Uguy, et al., 2015). a. Waktu pelayanan di perairan adalah sejak kapal berada di lego jangkar sampai ikat tali di tambatan dan sebaliknya.

1) Waiting Time atau waktu tunggu. Pelayanan PT. Pelindo IV cabang Manado dimulai sejak kapal di perairan pelabuhan. Waiting time disini adalah waktu kapal menunggu pelayanan tambatan, pelayanan pandu atau tunda.

2) Postpone Time atau waktu tertunda yang tidak bermanfaat selama kapal berada di perairan pelabuhan antara lokasi lego jangkar sebelum/ sesudah melakukan kegiatan yang dinyatakan dalam satuan jam.

3) Approach Time atau waktu atau jumlah jam yang dipergunakan selama pelayanan pemanduan, sejak kapal bergerak dari lego jangkar sampai ikat tali di tambatan dan sebaliknya.

b. Waktu pelayanan di tambatan adalah dihitung sejak ikat tali di tambatan sampai lepas tali, atau jumlah jam selama kapal berada di tambatan.

1) Turn Round Time (TRT) atau waktu pelayanan kapal di pelabuhan adalah jumlah jam selama kapal berada di pelabuhan yang dihitung sejak kapal tiba di lokasi lego jangkar sampai kapal berangkat meninggalkan lokasi lego jangkar, dinyatakan dalam satuan jam.

2) Berthing Time (BT) atau waktu tambat adalah jumlah jam selama kapal berada di tambatan, sejak kapal ikat tali sampai lepas tali di tambatan.

3) Effective Time (ET)/ Operation Time $(O T)$ atau waktu efektif adalah jumlah riil yang dipergunakan untuk melakukan kegiatan bongkar muat dinyatakan dalam jam.

4) Not Operation Time (NOT) atau waktu tidak kerja adalah jumlah jam yang direncanakan kapal tidak bekerja selama 
berada di tambatan, termasuk waktu istirahat dan waktu menunggu buruh, serta waktu menunggu akan lepas tambat kapal dinyatakan dalam satuan jam.

5) Idle Time (IT) atau waktu terbuang adalah jumlah jam kerja yang tidak terpakai selama waktu kerja bongkar muat di tambatan.

\section{Terminal Petikemas}

Terminal Petikemas adalah tempat tertentu di daratan dengan batas-batas yang jelas, dilengkapi dengan prasarana dan sarana angkutan barang untuk tujuan ekspor dan impor dengan cara pengemasan khusus, sehingga dapat berfungsi sebagai pelabuhan (Soeharto, 1987).

Terminal petikemas terdiri dari:

a. Unit Terminal Petikemas (UTP)

UPT adalah terminal di pelabuhan yang khusus melayani petikemas dengan sebuah lapangan (yard), yang luas dan diperkeras untuk bongkar/muat dan menumpuk petikemas yang dibongkar atau yang akan dimuat ke kapal. Karena kapal petikemas tidak dilengkapi dengan alat bongkar muat, juga terdapat lapangan penimbunan untuk stacking container. Peralatan yang digunakan untuk memindahkan dan menimbun petikemas adalah top loader, straddle carrier, dan transtainer, sedangkan alat untuk pengangktannya adalah chassis, dan primer mover.

b. Container Yard (CY)

Container yard adalah kawasan di daerah pelabuhan yang digunakan untuk menimbun petikemas FCL yang akan dimuat atau dibongkar dari kapal.

c. Container Freight Station (CFS)

Contaner freight station adalah kawasan yang digunakan untuk menimbun petikemas LCL, melaksanakan stuffing unstuffing, dan untuk menimbun break-bulk cargo yang akan di stuffing ke petikemas atau di unstuffing dari petikemas

d. Inland Container Depot (ICD)
Inland container depot adalah kawasan di pedalaman atau diluar daerah pelabuhan yang berada dibawah pengawasan bea dan cukai yang digunakan untuk menimbun petikemas FCL yang akan diserahkan kepada consignee atau diterima dari shipper (Suyono, 2001).

\section{LANDASAN TEORI}

Standar Kinerja Pelayanan Operasional Pelabuhan

Berdasarkan Keputusan Direktur Jenderal Perhubungan Laut Nomor UM.002/38/18/DTM-11 tentang standar kinerja pelayanan operasional pelabuhan, bahwa indikator kinerja pelayanan operasinal pada bab 3 pasal 3 terdiri dari:

a. waktu tunggu kapal (Waiting Time/WT), yaitu waktu yang dihitung sejak pengajuan permohonan tambat setelah kapal tiba di lokasi labuh sampai kapal digerakkan menuju tambatan,

b. waktu pelayanan pemanduan (Approach Time/AT), adalah jumlah waktu terpakai untuk kapal bergerak dari lokasi labuh sampai ikat tali ditambatan atau sebaliknya,

c. waktu efektif (Effective Time/ET), merupakan jumlah jam bagi suatu kapal yang benar-benar digunakan untuk kegiatan bongkar muat selama kapal berada di tambatan,

d. Berth Time/BT, jumlah waktu siap operasi tambatan untuk melayani kapal,

e. Tingkat penggunaan dermaga (Berth Occupancy Ratio/BOR), yaitu perbandingan antara waktu penggunaan dermaga dengan waktu yang tersedia (dermaga siap operasi), dalam periode waktu tertentu yang dinyatakan dalam persentase, adapun persamaan-persamaan dalam perhitungan BOR yaitu dihitung berdasarkan jenis tambatan.

1) Tambatan Tunggal

Perhitungan pada dermaga yang menggunakan 1 tambatan tidak dipengaruhi oleh panjang kapal yang 
dilayani dan nilai BOR dapat dihitung dengan menggunakan persamaan berikut:

$$
B O R=\frac{\text { swaktu tambat }}{\text { waktu efektif }} \times 100 \%
$$

2) Dermaga untuk beberapa tambatan

Dermaga dengan tambatan lebih dari satu atau beberapa tambatan sangat dipengaruhi oleh ukuran panjang kapal dan jarak jagaan antara kapal dalam perhitungannya sehingga persamaan dapat ditulis sebagai berikut:

$$
B O R=\frac{\Sigma(\text { Loa }+ \text { Jagaan }) \times \text { Waktu Tambat }}{\text { Waktu Efektif } \times \text { Panjang Tambatan }} \times 100 \%
$$

3) Tambatan secara umum Dalam perhitungan tingkat pemakaian dermaga dapat menggunakan persamaan berikut:

$$
\text { BOR } \frac{\text { Vs.St }}{\text { Waktu Efektif.n }} 100 \%
$$

Berdasarkan standar UNCTAD (United Nation Conference on Trade and Development), pemakaian dermaga tidak melebihi nilai yang telah ditentukan pada Tabel 2 berikut:

Tabel 1 Nilai BOR yang disarankan

\begin{tabular}{cc}
\hline $\begin{array}{c}\text { Jumlah Tambatan dalam } \\
\text { Group }\end{array}$ & $\begin{array}{c}\text { Bor yang } \\
\text { disarankan }(\%)\end{array}$ \\
\hline 1 & 40 \\
2 & 50 \\
3 & 55 \\
4 & 60 \\
5 & 65 \\
$6-10$ & 70 \\
\hline
\end{tabular}

(Sumber: UNCTAD, 1978)

f. Tingkat penggunaan lapangan penumpukan (Yard Occupancy Ratio/YOR) yaitu perbandingan antara jumlah penggunaan ruang penumpukan dengan ruang penumpukan yang tersedia dihitung dalam satuan ton hari atau satuan $\mathrm{m}^{3}$ hari, dengan persamaan

$$
\text { YOR } \frac{\text { Kapasitas terpakai }}{\text { Kapasitas tersedia }} 100 \%
$$

g. Kesiapan operasi peralatan yaitu perbandingan antara jumlah peralatan yang siap untuk dioperasikan dengan jumlah peralatan yang tersedia dalam periode waktu tertentu

\section{Pencapaian Kinerja Pelayanan Operasional}

Berdasarkan pasal 4 ayat 1 pada Surat Keputusan Direktur Jernderal Perhubungan Laut percapaian kinerja operasional dari setiap indicator dapat ditetapkan sebagai berikut:

1. nilai capaian yang berada dibawah standar yang telah ditetapkan dapat dinyatakan baik,

2. pencapaian nilai diatas $0 \%$ hingga $10 \%$ diatas standar yang telah ditentukan maka dapat dinyatakan cukup baik,

3. nilai capaian dinyatakan kurang baik apabila berada diatas $10 \%$ dari nilai standar kinerja operasinal yang telah ditetapkan.

\section{Panjang Dermaga}

Penentuan panjang dermaga disuatu pelabuhan dipengaruhi oleh jumlah arus kapal dan arus barang yang bertambat dan melakukan bongkar muat, sehingga dapat dihitung dengan persamaan berikut ini

$$
\begin{aligned}
& \quad n=\frac{V s S t}{\text { Waktu Efektif } \times B O R} \\
& L=n(\text { Loa }+10 \% \text { Loa })+10 \% \text { Loa } \\
& \text { Tingkat Pemanfaatan Lapangan } \\
& \text { Penumpukan }
\end{aligned}
$$

\section{Tingkat Pemanfaatan Lapangan Penumpukan}

(Purnomo, et al., 2014), Jumlah pemakaian fasilitas lapangan penumpukan dapat dihitung dengan persamaan 3 , dimana perhitungan dilakukan dengan membandingkan jumlah pemakaian gudang penumpukan dalam satu tahun dengan kapasitas penumpukan yang tersedia. Namun sebelumnya perlu dilakukan perhitungan kebutuhan luas lapangan penumpukan dengan menggunakan persamaan matematika berikut: 


$$
A=\frac{T \cdot D \cdot S f}{365 \times \operatorname{Sth} \times(1-B S)}
$$

\section{Peralatan Penanganan Petikemas}

(Triatmodjo, 2010) Penanganan pada terminal petikemas menggunakan peralatan khusus, penanganan khusus yang sedikit berbeda dengan penanganan barang umum (General Cargo), adapun peralatan yang digunakan meliputi peralatan seperti Quai Gantry Crane $(G C)$, Rubber Tyred Gantry Crane (RTG), atau Transtainer, Straddle Carrier, Head Truck, dan Chassis top loader, Forklift, Side Loader.

Persamaan matematika yang digunakan untuk menghitung kemampuan peralatan dalam menangani kegiatan bongkar muat petikemas adalah sebagai berikut:

a. Quai Gantry Crane (GC)

Beberapa variabel yang berpengaruh dalam penentuan kapasitas quai gantry crane $(G C)$ yaitu:
1) Jumlah GC
: n1 unit
2) Kecepatan pelayanan : $\mathrm{V}_{1}$ box/GC/jam
3) Waktu kerja dalam satu tahun: T1 jam

Dengan menggunakan variabel-variabel tersebut maka throughput capacity alat dapat dihitung sebagai berikut:

1) Throughput Capacity $G C: \mathrm{Tc}_{\mathrm{GC}}=\mathrm{V}_{1} \mathrm{~T}_{1}$ box/GC/jam

2) Kapasitas Terpasang $\mathrm{K}_{\mathrm{TGC}}=\mathrm{Tc}_{\mathrm{GC}} \mathrm{n}_{1}$ box/tahun

b. Rubber Tyred Gantry Crane (RTG)

Untuk perhitungan matematis dalam penentuan kapasitas Rubber Tyred Gantry Crane (RTG), harus melibatkan beberpa variable berikut:

1) Jumlah RTG : n2 unit

2) Kecepatan Pelayanan : $\mathrm{V}_{2}$ box/RTG/Jam

3) Waktu kerja dalam satu tahun : $t_{2}$ jam

Dengan menggunakan variabel-variabel diatas maka throughput capacity alat dapat dihitung, sebagai berikut.

1) Throughput Capacity $R T G: \mathrm{Tc}_{\mathrm{RTG}}=$ $\mathrm{V}_{2} \mathrm{t}_{2}$ box/RTG/Jam.

2) Kapasitas terpasang : $\mathrm{K}_{\mathrm{TRTG}}=\mathrm{Tc}_{\mathrm{RTG}} \mathrm{n}_{2}$ box/tahun.

\section{Regresi Linear Sederhana}

Regresi adalah suatu proses memprediksi secara sistematis tentang apa yang paling mungkin terjadi di masa yang akan datang berdasarkan informasi masa lalu dan sekarang dimiliki agar dapat meminimalisir tingkat kesalahannya atau meningkatkan tingkat akurasi hasil perhitungan, Persamaan yang digunakan untuk mendapatkan garis regresi pada data diagram pencar disebut persamaan regresi sebagai mana ditulis pada persamaan 8 berikut:

$$
y=a+b X
$$

\section{METODE PENELITIAN}

Pada penelitian ini penulis menggunakan metode kuantitatif, karena beberapa data lebih didominasi oleh data kuantitatif seperti angka, tabel, dan persentase, dimana metode tersebut menurut penulis mampu memberi gambaran dan penjelasan terkait fenomena yang diteliti, kemudian motede penelitian kuantitatif juga merupakan penelitian ilmiah yang menciptakan gambaran menyeluruh dan kompleks, serta terperinci.

\section{HASIL DAN PEMBAHASAN}

\section{Fasilitas Pelabuhan Makassar}

Aktivitas di pelabuhan mulai dari kegiatan administrasi hingga kegiatan teknis di lapangan sangat dipengaruhi oleh kelengkapan fasilitas pelabuhan, untuk detail fasilitas terminal petikemas dapat dilihat pada Tabel 4 hingga 6.

Tabel 3. Fasilitas Pokok Terminal Petikemas Pelabuhan Soekarno Hatta

\begin{tabular}{clc}
\hline No & \multicolumn{1}{c}{ Uraian } & Sat \\
\hline 1 & Berth Length & $850 \mathrm{~m}$ \\
2 & Draft & $9 \mathrm{~m}-11.5 \mathrm{~m}$ \\
3 & Chanel Depth & $-15 \mathrm{~m} \mathrm{sd}-17 \mathrm{~m}$ \\
4 & Custom Area & $6000 \mathrm{~m} 2$ \\
5 & Workshop & $4000 \mathrm{~m} 2$ \\
6 & Container Yard & \\
& Total Area & $126.400 \mathrm{~m} 2$
\end{tabular}


Jurnal Ilmu Sosial dan Pendidikan

http://ejournal.mandalanursa.org/index.php/JISIP/index

Terakreditasi Peringkat 5 (No. SK: 85/M/KPT/2020)

Kapasitas $\quad 700.000$ TEUs/Year

(Sumber:PT.Pelindo IV Cabang Makassar:2018)

Tabel 4. Peralatan Bongkar Muat Terminal Petikemas Pelabuhan Soekarno Hatta

\begin{tabular}{cllc}
\hline No & \multicolumn{1}{c}{ Uraian } & Volume & \multicolumn{1}{c}{ Kapasitas } \\
\hline & Container & & 25 \\
1 & Crane & 7 Units & $\begin{array}{l}\text { Boks/Jam } \\
7\end{array}$ \\
2 & RTG & 18 Units & Boks/Jam \\
3 & Reachstacker & 2 Units & - \\
4 & Side Loader & 1 Unit & - \\
5 & Forklift 32 ton & 1 Unit & - \\
6 & Forklift 7 ton & 2 Units & - \\
7 & Forklift 2,5 ton & 6 Units & - \\
8 & Head Truck & 34 Units & - \\
9 & Chassis & 36 Units & - \\
10 & Reffer Plug & 70 Units & - \\
\hline
\end{tabular}

(Sumber:PT.Pelindo IV Cabang Makassar:2018)

Tabel 5. Fasilitas Penunjang Terminal Petikemas Pelabuhan Soekarno Hatta

\begin{tabular}{clc}
\hline No & \multicolumn{1}{c}{ Uraian } & Volume \\
\hline 1 & Workshop & $2000 \mathrm{~m} 2$ \\
2 & Ops.Control Office & $150 \mathrm{~m} 2$ \\
3 & Truck Cons Area & $6000 \mathrm{~m} 2$ \\
4 & Gate & $4 \mathrm{Unit}$ \\
5 & IT System & CTOS + VGM \\
6 & Power Supply & $2 \times 800 \mathrm{Kva}$ \\
7 & Mobil PMK & 1 Unit \\
8 & Reservoar & $1000 \mathrm{Ton}$ \\
9 & Genset & 3 Units \\
10 & Tanki BBM & $16.400 \mathrm{Liter}$ \\
11 & Mini Power Station & $600 \mathrm{~m} 2$ \\
\hline Sumber:PT.Pelindo IV Cabang Makassar:2018)
\end{tabular}

Kunjungan Kapal dan Arus Petikemas

Penerapan system direct call serta pelayanan 24 jam sangat berperan dalam peningkatan jumlah kunjungan kapal di terminal petikemas Makassar, hingga tahun 2017, pihak manajemen TPM telah mencatat sekitar 1.544
Vol. 5. No. 2 Maret 2021

p-ISSN: 2598-9944 e- ISSN: 2656-6753

kunjungan kapal kontainer, sangat jelas terlihat bahwa terjadi peningkatan jumlah kunjungan kapal dari tahun ke tahun sebagaimana ditunjukkan pada Tabel 6 berikut.

Tabel 6. Kunjungan Kapal Tahun 2013-2017

Tahun Kunjungan Kapal (Call)

\begin{tabular}{ll}
\hline 2013 & 1.117 \\
2014 & 1.255 \\
2015 & 1.366 \\
2016 & 1.514 \\
2017 & 1.544 \\
\hline
\end{tabular}

(Sumber:PT.Pelindo IV Cabang Makassar:2018)

Meskipun arus petikemas cenderung mengalami siklus naik turun dalam pengiriman maupun penerimaan akan tetapi hal tersebut mampu mempengaruhi kenerja lapangan penumpukan serta kinerja alat angkat di terminal petikemas Makassar, pada Tabel 7 dapat dilihat siklus arus barang 5 tahun terakhir.

Tabel 7 Arus Petikemas 5 Tahun Terakhir

\begin{tabular}{ccc}
\hline No & Tahun & $\begin{array}{c}\text { Arus Barang } \\
\text { TEUs }\end{array}$ \\
\hline 1 & 2013 & 526045 \\
2 & 2014 & 534149 \\
3 & 2015 & 530948 \\
4 & 2016 & 580590 \\
5 & 2017 & 579551
\end{tabular}

(Sumber:PT.Pelindo IV Cabang Makassar:2018)

\section{Tingkat Pemanfaatan Dermaga Saat ini}

Dermaga terminal petikemas pelabuhan Soekarno Hatta Makassar memiliki panjang 850 $\mathrm{m}$, dengan tipe dermaga yaitu wharf, kapasitas tambat sebanyak 5 kapal dan dilengkapi fasilitas alat angkat disisi dermaga serta jalan akses untuk kendaraan berupa alat angkat pendukung lainnya, diketahui untuk operasional pada tahun 2017 tercatat sebanyak 1.544 kapal yang melakukan bongkar muat di dermaga tersebut, ukuran kapal terpanjang yang dilayani di dermaga tersebut yaitu $221.62 \mathrm{~m}$, dan memiliki panjang jarak antar kapal yaitu $20 \mathrm{~m}$ untuk kapal 
ukuran besar, lama waktu tambat untuk setiap kapal yaitu 16 jam dan waktu tersedia selama 1 tahun yaitu 8760 jam, sedangkan untuk BOR yang disarankan oleh UNCTAD yaitu $65 \%$. Sehingga untuk mengetahui tingkat pemanfaatan dermaga terminal petikemas Makassar dapat menggunakan persamaan 2 yang tertera pada bab sebelumnya. Untuk lebih jelasnya dapat diuraikan sebagi berikut:

$$
\begin{aligned}
\text { BOR } & =\frac{1.544 \times \frac{16}{24}}{365 \times 5} \times 100 \% \\
& =56.4 \%
\end{aligned}
$$

Hasil perhitungan tingkat pemanfaatan dermaga untuk saat ini diketahui sebesar 56.4\% nilai tersebut berada dibawah standar yang disarankan oleh UNCTAD yaitu $65 \%$, hal ini menunjukkan bahwa dermaga terminal petikemas memiliki kinerja yang baik.

\section{Tingkat Penggunaan Lapangan Penumpukan}

Menghitung kebutuhan luas lapangan penumpukan dengan menggunakan persamaan 5 , berdasarkan data arus barang pada Tabel 8 tahun 2017.

Diketahui:

Arus petikemas tahun 2017 : 579.551 TEUs

$$
\text { Dwelling Time : } 5 \text { hari }
$$

Luas yang diperlukan untuk 1 TEU: $10 \mathrm{~m}^{2}$

$$
\text { Broken Stowage } \quad: 30 \%
$$

Penyelesaian:

$$
\begin{aligned}
A & =\frac{579551 \times 5 \times 29}{365 \times 3 \times 2,5(1-30 \%)} \\
& =43853 \mathrm{~m}^{2}=4,4 \mathrm{Ha}
\end{aligned}
$$

luas lapangan penumpukan yang tersedia saat ini yaitu $126400 \mathrm{~m}^{2}$, telah memenuhi kebutuhan luas lapangan penumpukan untuk tahun 2017 sebesar $43853 \mathrm{~m}^{2}$. Untuk mengetahui tingkat pemanfaatan lapangan penumpukan pada tahun 2017, maka dapat dihitung dengan menggunakan persamaan 4, pada bab sebelumnya yaitu:

$$
\begin{gathered}
Y O R=\frac{43853}{126400} 100 \% \\
=34.7 \%
\end{gathered}
$$

Nilai YOR untuk operasional pada tahun 2017 sebesar $34.7 \%$ hal ini menunjukkan bahwa kinerja pelabuhan saat ini baik. Hal karena nilai YOR berada dibawah standar yang disyaratkan UNCTAD yaitu sebesar 65\%, sebagaimana di jelaskan pada Keputusan Direktur Jenderal Perhubungan Laut Nomor UM.002/38/18/DMT11 tentang standar kinerja pelayanan operasional pelabuhan, bahwa nilai capaian dinyatakan baik apabila berada dibawah standar $65 \%$ dari nilai standar kinerja operasional yang telah ditetapkan, sehingga berdaarkan hasil perhitungan makan manajemen terminal petikemas hanya perlu memaksimalkan lapangan penumpukan yang ada saat ini.

\section{Kinerja Peralatan Bongkar Muat Terminal Petikemas}

Peralatan bongkar muat memiliki peran yang sangat penting terhadap kelancaran operasional di terminal petikemas, baik untuk menaikkan barang yang akan di ekspor maupun menurunkan barang hasil impor ke lapangan penumpukan yang tersedia, mengingat keberadaan dan kinerja peralatan sangat dibutuhkan maka untuk maksimalisasi fungsi peralatan perlu diketahui seberapa besar kemampuan peralatan bongkar muat yang tersedia di terminal petikemas Makassar saat ini. diketahui jumlah hari kerja yaitu 365 hari, dengan waktu kerja yaitu 16 jam sehingga diketahui jumlah jam kerja adalah 5.840 jam/tahun, dan beberapa peralatan yang beroperasi khusus diterminal petikemas yaitu quai gantry carena $(G C)$, dan rubber tyred gantry crane (RTG).

a) Quai Gantry Crane

Melalui data sekunder dan hasil survey di lapangan diketahui jumlah GC 7 unit dengan kecepatan angkut sebanyak 25 boks/jam, sehingga dapat dihitung dengan menggunakan persamaan berikut: kapasitas Quai Gantry Crane: 
Jurnal Ilmu Sosial dan Pendidikan

http://ejournal.mandalanursa.org/index.php/JISIP/index

Terakreditasi Peringkat 5 (No. SK: 85/M/KPT/2020)

$\mathrm{GC}=25 \times 5.840=146.000 \mathrm{boks} / \mathrm{GC} / \mathrm{tahun}$

$=146.000 \times 1.3=189.800 \mathrm{TEUs} / \mathrm{GC} / \mathrm{tahun}$

kapasitas terpasang quai gantry crane:

$\mathrm{GC}=7 \times 189.800=1.328 .600 \mathrm{TEUs} / \mathrm{tahun}$

\section{b) Rubber Tyred Gantry Crane}

Diketahui bahwa jumlah RTG sebanyak 18 unit, kapasitas angkut 7 boks/jam, jam kerja selama 16 jam, sehingga dapat dihitung kapasitas RTG dengan menggunakan persamaan sebagai berikut:

kapasitas rabber tyred gantry crane

$\mathrm{RTG}=7 \times 5.840=40.880 \mathrm{box} / \mathrm{RTG} / \mathrm{tahun}$

$=40.880 \times 1.3=53.114 \mathrm{TEUs} / \mathrm{RTG} / \mathrm{tahun}$

kapasitas terpasang

$\mathrm{RTG}=18 \times 53.114=956.592 \mathrm{TEUs} / \mathrm{tahun}$

Jadi untuk mengetahui kinerja alat angkat atau tingkat pemanfaatan alat angkat dapat dilihat pada Tabel 8 .

Tabel 8. Kinerja Alat Angkat

\begin{tabular}{lccccc}
\hline Jenis Alat & $\begin{array}{c}\text { Arus } \\
\text { Petikemas } \\
\text { rerata } \\
\text { (TEUs/hari) } \\
{[\mathrm{b}]}\end{array}$ & $\begin{array}{c}\text { Jumlah Jam } \\
\text { Kerja } \\
\text { (jam/hari) }\end{array}$ & $\begin{array}{c}\text { Kapasitas } \\
\text { Alat Angkat } \\
\text { (box/jam) }\end{array}$ & $\begin{array}{c}\text { Jumlah Alat } \\
\text { Terpakai } \\
\text { (Unithari) }\end{array}$ & $\begin{array}{c}\text { Kinerja } \\
\text { Alat } \\
(\%)\end{array}$ \\
\hline $\begin{array}{l}\text { Quai Gantry } \\
\text { Crane }\end{array}$ & 1588 & 16 & 25 & 3,97 & 57,14 \\
$\begin{array}{l}\text { Rubber Tyred } \\
\text { Gantry Crane }\end{array}$ & 1588 & 16 & 7 & 14,18 & 78,77 \\
\hline
\end{tabular}

\section{Prediksi Arus Kapal dan Arus Petikemas}

Prediksi arus kapal dan arus petikemas

untuk 10 tahun mendatang yaitu tahun 2027 dapat diprediksi dengan menggunakan data series call kapal 5 tahun terakhir dan data series arus barang pada tahun 2013 hingga tahun 2017, perhitungan ini bertujuan untuk mengetahui jumlah kunjungan kapal di terminal peti kemas dimasa yang akan datang dan mengetahui seberapa besar arus barang yang akan dilayani oleh TPM, prediksi kunjungan kapal ini menggunakan metode regresi linear sederhana dimana metode tersebut diharapkan mampu mengambarkan kondisi sebenarnya yang terjadi di lapangan dan untuk menghasilkan persamaan tersebut maka dilakukan berdasarkan Gambar 17 berikut.
Vol. 5. No. 2 Maret 2021

p-ISSN: 2598-9944 e- ISSN: 2656-6753

\section{Regresi Arus Kapal}

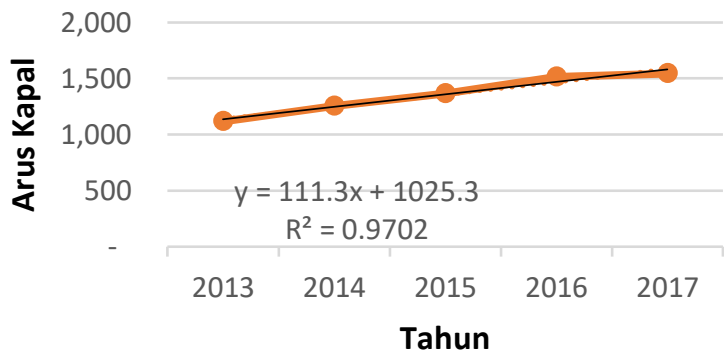

Gambar 17 Grafik Regresi Kunjungan Kapal

Diketahui persamaan untuk proyeksi kunjungan kapal 10 tahun kedepan yaitu: $y=111,3 x+1025,3$

hasil prediksi arus kapal 10 tahun kedepan, dapat dilihat pada Tabel 9.

Tabel 9 Prediksi kunjungan kapal

\begin{tabular}{rrc} 
No & Tahun & Kunjungan Kapal (Call) \\
\hline 1 & 2013 & 1.117 \\
2 & 2014 & 1.255 \\
3 & 2015 & 1.366 \\
4 & 2016 & 1.514 \\
5 & 2017 & 1.544 \\
6 & 2018 & 1.693 \\
7 & 2019 & 1.804 \\
8 & 2020 & 1.916 \\
9 & 2021 & 2.027 \\
10 & 2022 & 2.138 \\
11 & 2023 & 2.250 \\
12 & 2024 & 2.361 \\
13 & 2025 & 2.472 \\
14 & 2026 & 2.584 \\
15 & 2027 & 2.695 \\
\hline
\end{tabular}

(Sumber: Analisis Data, 2018)

sedangkan untuk prediksi arus petikemas juga menggunakan metode yang sama untuk memperoleh persamaan tersebut dapat dilihat pada Gambar 18 berikut: 
Jurnal Ilmu Sosial dan Pendidikan

http://ejournal.mandalanursa.org/index.php/JISIP/index

Terakreditasi Peringkat 5 (No. SK: 85/M/KPT/2020)

\section{Regresi Arus Petikemas}

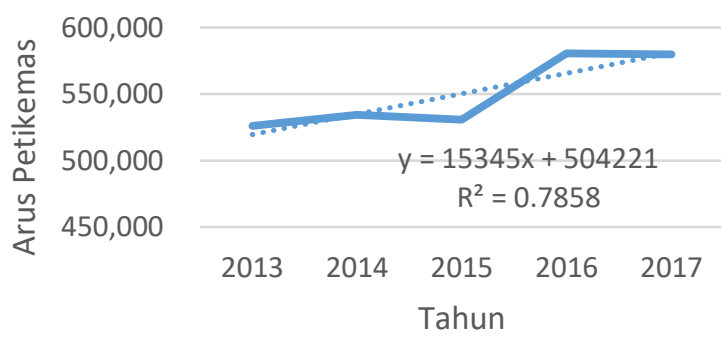

\section{Gambar 18 Grafik Regresi Arus Petikemas}

Hasil perhitungan menunjukan peningkatan yang sangat signifikan dari tahun 2017 dengan jumlah arus petikemas sebesar 579.551 TEUs menjadi 734.396 TEUs pada tahun 2027, sebagai mana tertera pada Tabel 10.

Tabel 10. Prediksi arus petikemas

\begin{tabular}{ccc}
\hline No & Tahun & $\begin{array}{c}\text { Arus Petikemas } \\
\text { TEUs }\end{array}$ \\
\hline 1 & 2013 & 526045 \\
2 & 2014 & 534149 \\
3 & 2015 & 530948 \\
4 & 2016 & 580590 \\
5 & 2017 & 579551 \\
6 & 2018 & 596291 \\
7 & 2019 & 611636 \\
8 & 2020 & 626981 \\
9 & 2021 & 642326 \\
10 & 2022 & 657671 \\
11 & 2023 & 673016 \\
12 & 2024 & 688361 \\
13 & 2025 & 703706 \\
14 & 2026 & 719051 \\
15 & 2027 & 734396 \\
\hline
\end{tabular}

(Sumber: Analisis Data, 2018)

\section{Analisis Kebutuhan Dermaga 10 Tahun Kedepan}

Berdasarkan hasil prediksi arus kapal untuk 10 tahun kedepan pada Tabel 8 diketahui terjadi peningkatan setiap tahunnya sehingga perlu dilakakn analisis tingkat penggunaan
Vol. 5. No. 2 Maret 2021

p-ISSN: 2598-9944 e- ISSN: 2656-6753

dermaga pada tahun 2027, untuk perhitungan tersebut dapat dilakukan dengan menggunakan persamaan 3 .

diketahui:

Panjang kapal (Loa) $\quad: 221.62 \mathrm{~m}$

Jumlah Tambatan $\quad: 5$

Kunjungan kapal (tahun 2027): 2.695

Waktu tambat $\quad: 16$ jam

Waktu efektif : 365 jam

BOR yang disarankan untuk dermaga 5 tambatan: $65 \%$

Jadi:

Nilai BOR untuk 10 tahun mendatang, dapat dihitung dengan persamaan 2 ,

$$
\begin{aligned}
\text { BOR }(2027)= & \frac{2695 \times \frac{16}{24}}{365 \times 5} 100 \% \\
& =98.4 \%
\end{aligned}
$$

Hasil perhitungan nilai BOR sebesar 98.4\% untuk 10 tahun mendatang, nilai tersebut lebih besar dari nilai yang disarankan oleh UNCTAD yaitu $65 \%$, hal ini menunjukan bahwa terjadi penumpukan kapal di area pelabuhan, terjadinya penumpukan dikarenakan panjang dermaga yang tersedia tidak sebanding dengan jumlah kapal yang akan tambat didermaga tersebut.

\section{Analisis Kebutuhan Lapangan Penumpukan 10 Tahun Kedepan}

Berdasarkan data Tabel 9 hasil prediksi arus barang pada tahun 2027 yaitu sebanyak 734.396 TEUs untuk menghitung kebutuhan lapangan penumpukan dalam 10 tahun kedepan, dapat dihitung dengan menggunakan persamaan 7 sebagai berikut:

$$
A=\frac{T \cdot D \cdot S f}{365 \times \operatorname{Sth} x(1-B S)}
$$

diketahui:

Arus barang tahun 2027: 734.396 TEUs

Dwelling Time :5 hari

Stowage Factor : $29 \mathrm{~m}^{3}$

Jumlah Tumpukan $\left(\mathrm{S}_{\mathrm{th}}\right): 3$

Broken Stowage : $30 \%$ 
penyelesaian:

$$
\begin{aligned}
A & =\frac{734.396 \times 5 \times 29}{365.3 .2,5(1-30 \%)} \\
& =55570 \mathrm{~m}^{2}
\end{aligned}
$$

Sehingga untuk mengetahui seberapa besar tingkat pemanfaatan lapangan penumpukan terminal petikemas Makassar hingga tahun 2027 maka dapat dihitung dengan menggunakan persamaan 4 pada bab sebelumnya:

$$
\begin{aligned}
Y O R & =\frac{55570}{126400} 100 \% \\
& =43.9 \%
\end{aligned}
$$

\section{Analisis Kebutuhan Alat Angkat 10 Tahun Kedepan}

Karena keterbatasan data maka jenis alat angkat yang di analisis dalam penelitian ini yaitu Container Crane dan Rubber tyred Gantry Crane dimana alat ini dipilih karena merupakan alat angkat utama yang memiliki kapasitas lebih besar jika dibandingkan dengan alat angkat yang lain, container crane berfungsi untuk memindahkan barang dari kapal ke dermaga dan dari dermaga ke kapal, sedangkan Rubber Tyred Gantry Crane berfungsi mengangkut barang dari dermaga menuju lapangan penumpukan dan melakukan penyusunan di area penumpukan tersebut, adapun hasil analisis dapat dilihat pada Tabel 12. Dari hasil perhitungan tersebut diketahui bahwa kinerja alat angkat di terminal petikemas Makassar, mampu menangani arus arang sebanyak 2012 boks atau setara dengan 2615.6 TEUs pada tahun 2027 mendatang, sehingga pihak manajemen terminal peti kemas hanya perlu memaksimalkan fungsi peralatan tersebut.

\section{Rencana Pengembangan Terminal Petikemas}

Berdasarkan hasil analisis untuk kebutuhan dermaga dan lapangan penumpukan petikemas serta alat angkat, maka diketahui untuk 10 tahun kedepan kebutuhan dermaga terminal petikemas telah mencapai $98.4 \%$ dimana capaian tersebut sangat mempengaruhi kinerja terminal petikemas itu sendiri sehingga perlu dilakukan rencana penanganan dini untuk mengantisipasi terjadinya penumpukan kapal di area pelabuhan, dengan menggunakan persamaan 5 pada bab sebelumnya maka dapat dihitung sebagai berukut:

$$
\begin{gathered}
n=\frac{\text { Vs St }}{\text { Waktu Efektif } \times \text { BOR }} \\
n=\frac{2.695 \times \frac{16}{24}}{365 \times 65 \%} \\
=7.6 \approx 8 \text { tambatan } \\
\mathrm{L}=8(221.62 \times 1.1)+0.10 \times 221.62 \\
=1.972 \mathrm{~m}
\end{gathered}
$$

Penambahan panjang dermaga dari $850 \mathrm{~m}$ pada Gambar 19 menjadi 1.972 m pada Gambar 20, hal ini dilakukan dalam rangka mengantisipasi terjadinya antrian kapal di area pelabuhan, untuk rekapitulasi data dapat dilihat pada Tabel 13

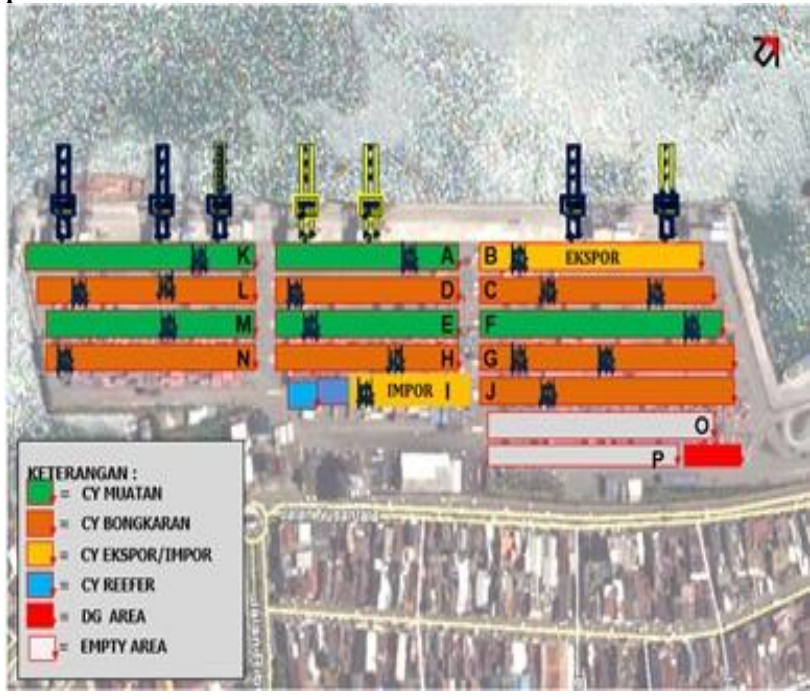

ambar 19 Layout Terminal Petikemas Saat ini Sumber: PT.Pelindo IV cabang Makassar, 2018) 
Jurnal Ilmu Sosial dan Pendidikan

http://ejournal.mandalanursa.org/index.php/JISIP/index

Terakreditasi Peringkat 5 (No. SK: 85/M/KPT/2020)

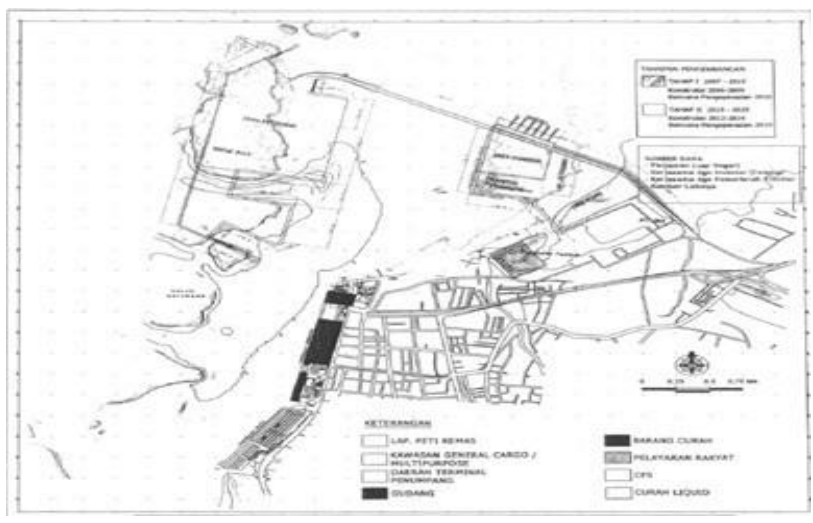

Gambar 20 Lauout Rencana Pengembangan Terminal Petikemas

\section{KESIMPULAN}

Setelah melakukan pengolahan data sekunder dan primer pada bab sebelumnya maka dapat ditarik beberapa kesimpulan dari hasil perhitungan tersebut.

1. Kinerja dermaga terminal petikemas Makassar saat ini dapat dinyatakan baik karena berdasarkan hasil perhitungan nilai BOR untuk kondisi eksisting yaitu 56.4\%, nilai tersebut berada dibawah standar yang disarankan oleh UNCTAD yaitu sebesar $65 \%$. Sedangkan untuk kinerja lapangan penumpukan pada saat ini yaitu tahun 2017 juga mengalami capaian kinerja yang baik karena bobot nilai YOR yaitu $34.7 \%$, atau setara dengan luas lapangan penumpukan 4.4 Ha karena nilai capaian YOR dibawah standar maka perlu mempertimbagkan jumlah tumpukan petikemas di lapangan penumpukan, diketahui semakin sedikit jumlah tumpukan maka akan semakin maksimal pemanfaatan lapangan penumpukan dan memperpanjang umur lapangan penumpukan akibat beban yang ditanggung oleh struktur perkerasan tidak terlalu berat.

2. Berdasarkan hasil perhitungan dengan menggunakan metode regresi linear sederhana diketahui jumlah kunjungan kapal untuk tahun 2027 adalah 2.695
Vol. 5. No. 2 Maret 2021

p-ISSN: 2598-9944 e-ISSN: 2656-6753

kunjungan atau setara dengan nilai BOR $98.44 \%$, sehingga dermaga terminal petikemas perlu melakukan penambahan panjang untuk memenuhi standar kinerja yang disarankan oleh UNCTAD, total tambatan yang dibutuhkan untuk 10 tahun kedepan yaitu 8 tambatan setara dengan $1.972 \mathrm{~m}$, penambahan panjang dermaga terminal petikemas tersebut dibagun sesui rencana pembangunan Makassar New Port, pada tahap 2 tahun 2025 ,detail penambahan panjang dermaga dapat dilihat pada Lampiran 1. Sedangkan untuk arus petikemas pada tahun 2027, mencapai 734.396 TEUs atau setara dengan nilai YOR $44 \%$, dengan kebutuhan luas lapangan penumpukan mencapai $55.616 \mathrm{~m}^{2}$, sehingga pihak manajemen terminal petikemas tidak perlu melakukan penambahan luas areal penumpukan terminal petikemas karena masih memenuhi standar yang disarankan oleh UNCTAD sebesar $65 \%$.

3. Diketahui jumlah arus petikemas pada tahun 2017 yaitu 1588 boks per hari dengan jumlah pemanfaatan alat angkat jenis Container Crane sebanyak 4 unit, jenis Rubber Tyred Gantry Crane sebanyak 14 unit. Jadi kinerja peralatan bongkar muat di terminal petikemas pelabuhan Soekarno Hatta Makassar masih mampu memenuhi kebutuhan alat bongkar muat untuk tahun 2017.

4. Hasil prediksi kebutuhan alat angkat diterminal petikemas Pelabuhan Soekarno Hatta Makassar untuk tahun 2027 dinyatakan mampu melayani arus barang sebanyak 2012 boks per hari, dengan jumlah pemanfaatan alat angkat berupa Container Crane sebanyak 5 unit dari total 7 unit yang tersedia dan alat angkat jenis Rubber tyred Gantry Crane sebanyak 18 unit dari 18 unit yang tersedia, jadi pihak manajemen terminal petikemas hanya perlu 
memaksimalkan fungsi alat angkat yang tersedi saat ini.

\section{SARAN}

Saran untuk pihak manajemen terminal petikemas dalam memaksimalkan fungsi terminal petikemas yaitu karena nilai YOR lapangan penumpukan jauh dibawah standar yang disarankan oleh UNCTAD maka terminal petikemas hanya perlu memaksimalkan penggunaan lapangan penumpukan sehingga dari kondisi eksisting diketahui jumlah tumpukan sebanyak 3 tumpukan maka untuk memaksimalkan lapangan, pihak manajemen terminal petikemas sebaiknya menumpuk petikemas dalam 2 tumpukan selain untuk memaksimalkan lapangan juga mampu mengurangi beban berat bagi perkerasan lapangan penumpukan, sehingga mampu memperpanjang umur perkerasan.

\section{DAFTAR PUSTAKA}

Ernawati, E., 2011. Proses Pemuatan Barang kedalam Container (Stuffing) pada CV. Manggala Java Art di Klaten, Tugas Akhir, Surakarta, Universitas Sebelas Maret.

Gunawan, H., Suhartono., Sianto, M.E., 2008. Analisis Faktor-faktor yang Berpengaruh Terhadap Produktivitas Bongkar Muat Kontainer di Dermaga Berlian Surabaya (Studi Kasus PT. Pelayaran Meratus), Widya Teknik, Vol.7 No.1

Hartanto, B., 2015, Optimalisis Kinerja Terminal Petikemas Pelabuhan Pontianak, Tesis, Universitas Gadjah Mada.

Jinca, M. Y., 2011. Transportasi Laut Indonesia, Analisis Sistem dan Studi Kasus. 1 ed. Surabaya: Brilian Internasional.

Negeri, P. K. P. L., 2014. Analisis Usulan Pelabuhan Bitung Sulawesi Utara sebagai pelabuhan tujuan impor produk tertentu, Jakarta.
Novrizal, A., 2014, Analisis Kinerja Operasional Pelabuhan Umum Tanjung Intan Cilacap, Tesis, Universitas Gadjah Mada.

Peraturan Menteri Perhubungan Nomor 83, Tahun 2016. Tentang Penyelenggaraan dan Pengusahaan Depo Petikemas.

Peraturan Pemerintah Republik Indonesia nomor 61, 2009. Kepelabuhanan, Jakarta: Peraturan Pemerintah Republik Indonesia.

Purnomo, A., Widodo, S. \& Erwin, K., 2014. Analisis Kapasitas Terminal Petikemas Pelabuhan Pontianak, Pontianak: s.n.

Pusat Kebijakan Perdagangan Luar Negeri, 2014. Analisis Usulan Pelabuhan Bitung Sulawesi Utara Sebagai Tujuan Impor Produk Tertentu, Jakarta: Kementrian Perdagangan Republik Indonesia.

Puteranto, I.W., 2015, Analisis Kelayakan Rencana Pengembangan Prasarana Transportasi Penyeberangan di Weda Kabupaten Halmahera Tengah, Tesis, Universitas Gadjah Mada.

Soeharto, 1987. Keputusan Presiden Republik Indonesia No 52 , Jakarta: Keputusan Presiden Republik Indonesia.

Surat Keputusan Direktur Jenderal Perhubungan Laut , 2011. Standar Kinerja Operasional Pelabuhan, Surat Keputusan Direktur Jenderal Perhubungan Laut.

Suyono, R., 2001. Shipping, Pengangkutan Intermodal Ekspor Impor Melalui Laut. Jakarta: PPM.

Timor, H.Z., 2014. Analisis Kinerja Terminal Multipurpose Nilam Timur Tanjung Perak Dari Aspek Produksi Petikemas, Tesis, Universitas Gadjah Mada.

Triatmodjo, B., 2010. Perencanaan Pelabuhan. Yogyakarta: Beta Offset.

Uguy, C. Y., Sendouw, T. K. \& Rumayar, A. L. E., 2015. Evaluasi Kinerja Operasional 
Pelabuhan Manado. Tekno, Volume 13.

UNCTAD, 1978. Port Development, A Handbook for Planners in Developing Countries, New York.

Undang-undang Republik Indonesia Nomor 17, Tahun 2008, tentang Pelayaran.

Widyarti, D. A., Rinaldi \& Fatnanta, F., 2017. Analisis Berth Occupancy Ratio (BOR), Untuk Memenuhi Standar Utilitas Dirjen PerhubunganLaut pada Dermaga B Curah Cair Pelabuhan Dumai. Jom FTEKNIK, 4(2).

Y.Goda, T. S., 2002. Technical Standard and Commentaries For Port and Harbour Facilities in Japan. Japan: The Overseas Coastal Area Development Institute of Japan.

Zanthy, L.S., 2016. Statistik Dasat Analisis Regresi Sederhana.STIKIP, Siliwangi 